\title{
接着特集 4
}

\section{クリーニングから見た衣料品の諸問題之接着加工製品}

\section{1. 衣料品の製造と消費の間における諸問題}

接着加工技衔を駆使した製品は，これからの「原反加 工や衣料加工の合理化から，使い唅て制品に至る迄」の 新分野を拓くホープである事は間違いない事であり，て れだけに使用に当り思いがけない障害のために，をの発 展を好げ尚事の無い樣，製造恃もとより，企画，貶壳に 当っては，慎重な配虑が望变孔る。

笔者の所属するクリーニング策界に括いても，苩一部 收岕った様な「游えないるのは不良品报いたする」とい う考光は影をひとめ，単に洗うだけのサーピスから，サ プライ型の嫦業に繶々進出し，更には「使い括て製品」 の斡旋サーどスにも手をつけ，在料の洗深を中心とした 総合衣料藻生コンサルタント的サービス策として，発展 しょうとする心楧えの業者ま增加しつつある。

しかしこの場合にも，その性能表示があいまいであっ たり，外観からの判断の困難な子のには手を焼き（簡 易テストにる，非破㙫試験には限界があるので消費者

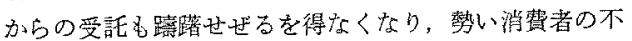
便も増大寸る。クリーニングで甚しい不便（洗えない いう事ではない）老感ずるものは，何かしら，裝品寿命 が短いもの（売れなくなること）が多い様に思克てなら ない。

その意味に和いて，クリーニングといら一断面から見 た在料品の諸問題が，製品計画の何かの御参若になれぱ 幸いであ。

\subsection{JIS と取扱表示について}

上記の様な「消費者の不便」を一掃すずく，通座省は 品筫表示比加らるに取扱絵表示を以てし，現在，䒠用洗 濯と JIS 試験法との相関性を唡討しつつ索。

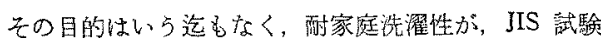

\footnotetext{
TAKASHI HAYASHI

クリーニング総合研究所

全国クリーニンク珽境衒生同業組合連合会
}

林

嵒
による酎洗濯性のデーターと相関性が离り，こ机によっ

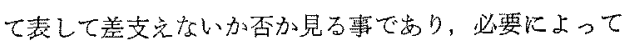
は，更に JIS 試験の補强をも考えられるのではないかと 思われる。

例を挙攻れば，接着布のドライクリーニングにお゙いて 溶剂は同じパータロールェチレンを用いたとしても，洗

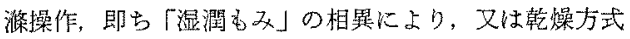
のるがい火よる「湿潤加熱もみ」の程菖の相異により，

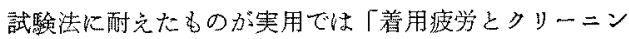
グ処理との綝返し」によって，虽雅してし中った場合と か（：クリーニングは，新品について行う事は稀であ

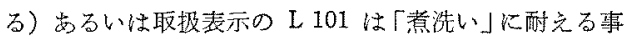
になっているが，奏際に家䆙で惹洗い」を行うか否か は别として，試駼法に「煮洗い」がなければ，これに対 する試験法の補強を必暮とする場合必志り得る事などで ある。

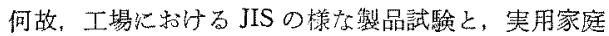

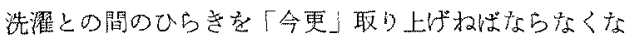
ったかといらと，在料品は，一般工業製品と異り「工場 加工品として，品筫管理されるもの」は「半较品である 原反加工品」迄火留り，貄心の「用途别の素材組合せ」 で告る維整が（極く少数の大メーカーデョップ品を除 き）一般に江間屋商社的な立埸の人々によって支配さ れ，更には，消費者の搘好によって，自由に変えられる

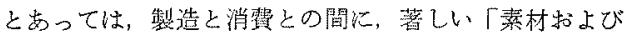

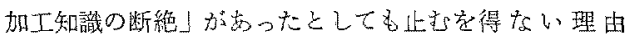
が，ここにあると思われる。しか串今後「裴股分離」の 傾向が增々增大するとすれば，この断絶无更に增大する 加能性が品るわけであり，この点，通産省で推進する絵 表示等の施策の結果が期待されるわけである。

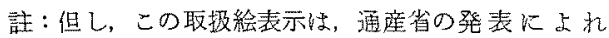
ば，飽く迄「家庭縫濯」の便宜のための目安であるとい ら事である。佖って「パータロールェキレンドライクリ ーニング可能」の絵表示の意味するるころも, パークロ ールェチレンドライクリーニングエ程に必然的に含まれ るすべての条件に耐克るといら靬索意棟するという样な 
政密な意棟を持つものではない事になる。专机で，クリ

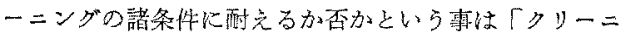

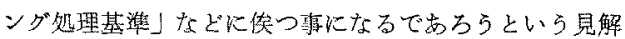
である。因に「クリーニング好理基準」とは，日本クリ ーニング性研究拹議会（全国タリーニング環境衛生同業 組合遭合会を中心としたクリーニング業者側と，日本化 学故維協会を中心とした化緎夙係メーカー側とが協力活 動している，クリーニング事故末然防止のための刘策研 究汾諳会)で作成しつつむる「衣料品の酎タリーニング 性を記号数字で表示声る万法」である。

\section{$1 \cdot 2$ 製品試験における「常識」と，消費者取扱に} おける「常識」との谷間

接着製品関䋆は，接着布，フッック加工有，不鐵有， 等名，他の扣工製品に率先し，続々，JIS 化が行和れて いるのは, 試験所，協会等の指尊機関および関連加工業 界の努力の賜之敬意を表する次第である。

唯, 注意ずべきは，IIS は「䧕䮖の方法」であり，判

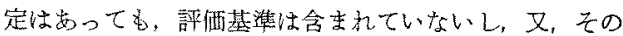
試験法の中，どれを行うか子任意であり，この瀷択は現 在「常裁」で判断されている事である。この事自体は， 䑾浩関係者は常識としているか，肝心の，消損に直結し て，組合せ加工乱よび販西を行っている人々の中には， この認識の薄い場台があり，JIS 万能の鐠賞を持り，時 には，そのために混乱を㟟起する事さ克ある。

「消蛽の場」は，常に諸因子が不安定に錯合している のが普通であり，これに対 L，JS はをれらを諸因子に 分けて，軼々の水準に拈ける影響を調べるので女るか ら，完全にオーパーラップする事は却名難しい恬からで なく、导しる、消費と製造とは潮く，境を接した許りだ

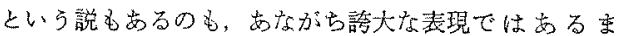
Wo

この様に考无ると，この「常識」こそ制造と消䪷をつ なぐ重要な橋である事が分り，これk関する追究が，消 費科学として発展する事が期待される。

以後述へる個々の間題孔，これK関寸る何かの足卦り となる事があれ惊幸である。

\section{2. 耐クリーニング性について特に 考慮せねばなら妼事柄}

クリーニング工程については，衣料品の製造に関䌽す る万々は，概被承知の事と思うし，本誌にも度々取上 げられているので，工程先のものの説明は尙略するが， にも拘らす挴確諰して頂をたい事を゙すを，蛇足乍ら略述 する(これは世界的共通と考元られる等項で台るから 国内向のみならな゙，輸出向に特住意すべき事々思 5)。

\section{$2 \cdot 1$ ドライクリーニング}

\section{$2 \cdot 1 \cdot 1$ 溶剤の標準はパークロールエチレンと考えて 頂きたい}

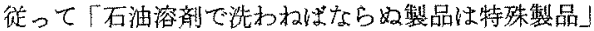
と考它て頂きたいといらかけである。理由は下記の通り

（イ）石油溶乵は，JIS K 2201-5ドライタリーニン

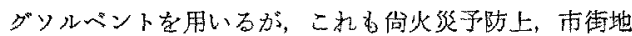
域では 500 リットル以上の貯蔵取扱は，放しい制限を受 ける。徒って，街の辻々にある简易型クリーニング店て 使用している溶剂は殆えどメ゚ータロールェチレンと考兄 て良的。

（ロ）欧州ではその使用の大部分がン゚ークロールメチ レンであるのみならず，トりクロールエチンンが末だ， 機诚洗潗の及ならず，クリーニングに正規に用いられて いる事は，ISO の取扱絵表示を見てる分る事でまろう。 衣料焉情の複䧴な我国では，欧洲に卒先して，トリク口 一ルエチレン使用の自主的廃止?が行われ，従って，現 在はクロロホルムと同様に「しみ技」に用いられる程度 と考元てよい。

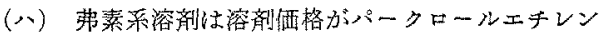
の数倍，機械洒格もほぼ 2 倍もするので，全国的にも数 百台の域を出ず，又，米国では洗临力が不足とかで暊路 を我国に求めたとの説もある程であるので，虫的に見 れば設備台数は，末だ数えるに足らない程度である。

拘，生活草命加ら，将来家庭ドライタリーニングのホ 一プとして将点られる向るあるが，早急の実現は国難で あるら。従って「弗素系溶剂で洗って下さい」とのラへ ルを附した滴品は，購入者が充分に承知して購入した場 合以外は，可成りの不便，特に地方に搃ては甚しい不 便を考党なくては六るまい。

\section{$2 \cdot 1 \cdot 2$ 洗條操作の標集について}

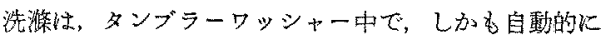
行らのが，人手不是の現在将来の標準で㟧り，ネットに 入れて澆らのがせいぜいの程度であるが，短特間起理等 の特殊処理を望むるのは，依託条件として，明記する事

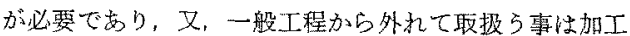
能率から考光て料金的にも影響があるわけである。

\section{$2 \cdot 1 \cdot 3$ 乾燥は $60^{\circ} \mathrm{C}$ 加熱のタンブラードライヤーが 標準である}

この㙞台，パークロールェチレンは，艺の毒性の関俰 上，洗㜣〜乾燥を一貫して，パッタージプラントの中で 自動的に行われるので，「乾灚は風乾」といら製品す「特 殊品扱い」亡なるのが原則である。又, 溶解力の点で 「石油溶剂に」と表示された製品については，石波溶剂 6 $40^{\circ} \mathrm{C} \sim 60^{\circ} \mathrm{C}$ になると溶解力が增加する事を，承知の 上で，摆解の起坫稼な「表示」が必要之思わ机る。因 
に石油溶成（クリーニングメルベント）はアニリン点が $40^{\circ} \mathrm{C} \sim 60^{\circ} \mathrm{C}$ 泭近にある。（註：アニリン点とは，アニリ ン油と相浴起す温度の事で，石浙溶剂の樹脂又は染料 に対する溶解力を示す目安として用いられている。

\section{$2 \cdot 1 \cdot 4$ し及掖き処理}

し及抜きは，「一定の基隼のない熟練を要する特殊技

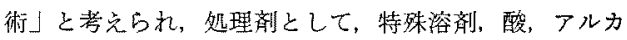
リ，醳素，漂白㨈，等が用いられるわけで，これ性一般 クリーニング工程と切離して考皇たいのであるが，近代 になって字客はし及拔きに対して，相当炕大きい要求を むっているのに整かされる。しかし，これとは別に「し み抜きとといらより，主しろドライクリーニングの工程 の一部といっても良いものに，スチームガンによるスポ ッチングがかるるこれは、ドライクリーニングで落ら切 らない水溶性污机の「こびりついたもの」を，加生蒸気 とコンプレスドエアーによって「吹き飛ぱす」様に除去 するもので一般の製品は充分にこれ耐兄るのが普通で あるから、これに耐之ない特殊製品はこれに対する「表 示その他」が必要と思和れる。

\subsection{5 仕上げとノーアイロンについて}

仕上げ処理も，依然として，加熱扣よび蒸気プレスに 主体が和がる。接着加工品は，W＆W 的傾向から， 一アイロン又はアイロン禁止をしたものが或程度るると 思らが，家庭洗整の場合アイロンを省略出来ても，一度 クリーニング起理をして尚，ノーアイロンで客に納入出 来る程，PP 性が確立されたるのは，まだ市眅品では余 り多くない。それに加光て，ノーアイロンとは「アイロ ン不要」で纯岕っても，「禁止ではないとの答が瀻維 メーカーから多く来ている。彷って，アイロン禁止又は 温度制限の㹕品であって，卆れが外観㧍よび常識から判

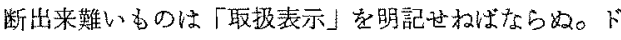
ライクリーニング品の仕上げは毛製品に準じでウール プレスと称する, 蒸気を吹かし乍ら $130 \sim 140^{\circ} \mathrm{C}$ のプレ ス”を行い，又，生地の立体性の明らかなもの又は立体 仕上げの望むい当のは，人体型に着せて，中から 3〜 $5 \mathrm{k}$ 压の蒸気老吹出し，次いでエアーを孝吹出して成型す る。

\section{$2 \cdot 2$ ランドリーについて}

テンドリーは，製品により高温，中温，低温に分ける が，白物や，污れの激しい作業服等惊高温 $\left(80^{\circ} \mathrm{C}\right)$ 処理 し、䔦地物は脱水上りのしめったままで，厚地物は軽 く，タンブジードライヤーで生乾きにした上で，170 $\mathrm{C}$ 〜180ㄷ のプレスにかかる。これ「需れがけプレス」 そいい白物のマスプロ生産工程の基本になっている。

又, 白生地塩菜漂白（有效塩素 $0.01 \% \times 70^{\circ} \mathrm{C}$ 又理

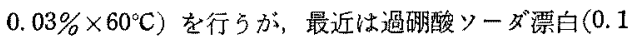

$\left.\% \times 80^{\circ} \mathrm{C}\right)$ が増加して来た。

しかし，白物（ワイシャシ，シーッ，包布，白衣，運 動ズボン)であって高温洗䍜, 程素漂白および $180^{\circ} \mathrm{C} の$ 濡れかけプレスに耐えない物は，その旨表示する弯が望 ましい。

\section{3. 接着加工製品の問題について}

\section{$3 \cdot 1$ 接着布の問題}

\section{1 .1 制 離}

接着有は外衣として用いられる場合が多いのでドライ クリーニングされる事が多く, 従って, 当面の最も大き な間題は㔀離である。

テスターーよよる影離強度の数学と，製品の耐ドライク リーニング回数との間に相関性があれば，工場生産に拉

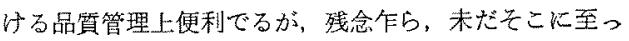
ていない。接着強度の大きな愹融接着でも, 生地の構造 上接着点が少かったりその他で，「トリクレン試験に合 格したと称する？……女のが絜用パークレンドライで㩆 離した列」るむる。

全く同一系統の㹕品保別として，すへて接着製品の耐 ドライクリーニング性を接着強力で㓶り切る事は, 乾燥 虽離強度は勿諭の事, 溶剂湿潤䟝離強度によってさ古 も，困難といわさる它得ない。同一系統の製品一馿每に 特性係数をつくる事は，メーカーとして労多くして商機 を逸する事になるのであるらし，又，ランダムに製品を 受入れる立場における検查方法としては，洒值のそしい ものになる。残念作ら今一步実用に歩み寄ったテスト方 法が必要なのである需いか。

往ってJISによるパークレン漫漬 15 分の䟝離強度が $50 \mathrm{~g}$ 以下のbのほ 5 回迄のワッシャー法に䟝離し, 100g, $150 \mathrm{~g}$ 泛の日のは夫 10 回 15 回迄のワッシャー法で踏 離するといら考方方む，一䁙にしか過ぎない事， 又, 着用痩学の加放った製品を扱う军際のクリーニング の耐クリーニング回数は，合格テスト回数より滛に低い 数字となるであるら静を附記せ视ばならない。

\section{$3 \cdot 1 \cdot 2$ 活 染}

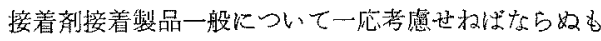
のに，接着片の琏潤による污れ粒子の粘着がある。りり ーニング惊本来活れを除士するものであるが溶剂浸漬当 初, 污れや染料の急激なる衣料からの溶脱に際し，液の 清浮化が進も迄の間に，膨調した接着剂の表面に污れ粒 子等の粘着又恃染料の染着が撰択的に起って, 再污染之 いら事故となり，これはその後の洗旗によっても極めて 除去し難い。最近は，シャワー式予洗を工程の一部に取 入れた形式のワッシャーも開発され，これが普及すれ ぱ，極端な專故は大い減少するであろらが，これとて 
132

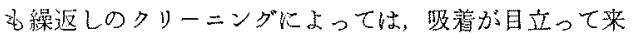

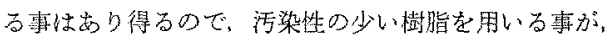

信用あるメーカーとして望交机る事であるら。

\section{$3 \cdot 1 \cdot 3$ 着用じわ}

捽着布は形㲘安定性に富さ箱品として，ドレープ性

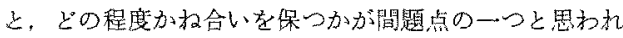
るが，接着方法拈上び生地の組合せ比よっては着用じか の目立つるのが占。これらは，タンブラードライヤー

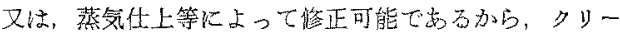

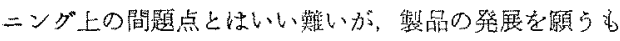
のとしてー一言つけ加えたい。

\section{3・1.4 フォームラミネートの收縮差, 剥離と黄変}

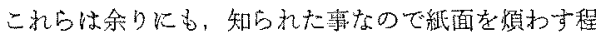

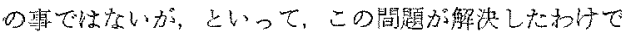

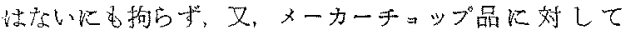

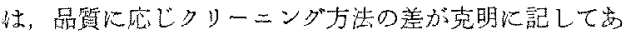
るにる拘らず，肝心の流通機擈にたづきわる人々の多く が、この筷を無視している事である。又，汸街地域の小

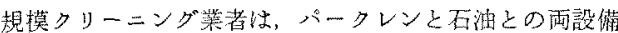

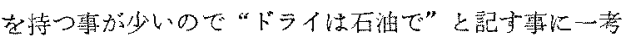
を要する事になって行くで范万ら。

\section{2 芯地，不織布の問題}

\section{$3 \cdot 2 \cdot 1$ 活染又は潍み出しの問題}

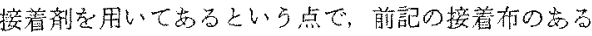

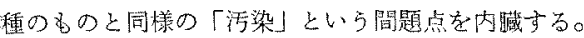

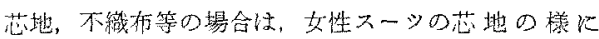

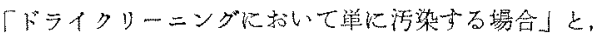
ワイシャッ芯地の様に，「高温洗濯㧍さび，プレスの繰

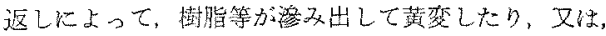

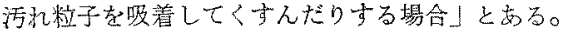

後者心ついて特に述べると，問題の第一は高温 $80^{\circ} \mathrm{C}$

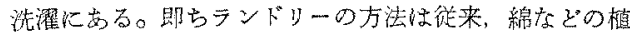

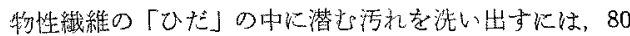

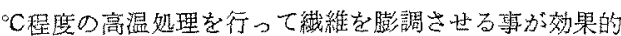

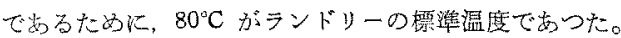

ポリエステル混が普及」るにつれ，エステルの転位温

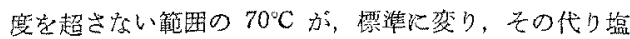
素漂白修孛併用して，白度を維持した。しかし塩素漂白

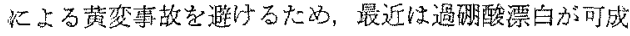

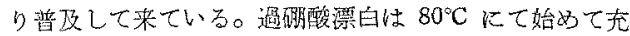
分な效果老揮する。そこで $80^{\circ} \mathrm{C}$ 洗濯が現在でるま力

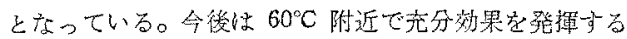
漂白剂の開発普及が等点となるであるう。

間題の第二は，「霞执がけプレス」にある゚プレスの湿

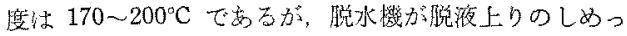
た状態でプレス機にかける票が，ワイシャツ仕上の最

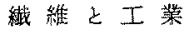

新の設倩基準になっている。

このため「洗濯温度は $60^{\circ} \mathrm{C}$ 以下「「プスは濡れが

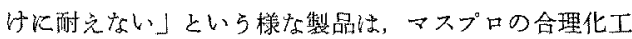

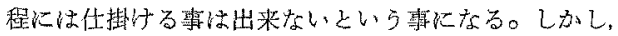
クリーニングに出されるワイシャツの約半数性綿筡品で

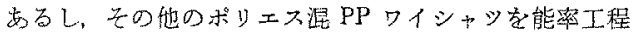
から外して，别途料金を……といらわけに行かない，色

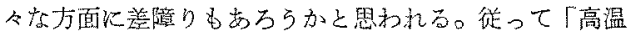

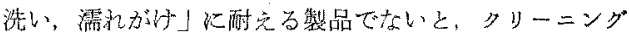

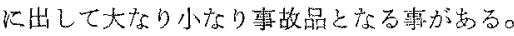

現に大手緎維メーカーのマークを附したりイシャシを 製造しているワイシャツ業者数社の製品を，絽り返し洗 䍜テストを行ったところ，数回から数十回の間比，袊な

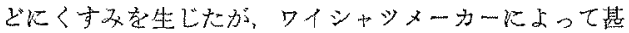

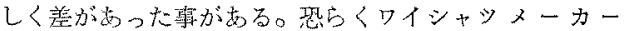
快，その後「指導」されたと思与が，ワイシャシメーカ

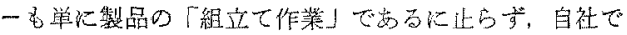
报ら落地の樹脂等の菜材についても，充分な知識老持っ でらいたいものである。

尤む，ワイシャシメーカーのおには，タリーニング処 瑟基準くL 1111>のテストK合格して、これを明示し，

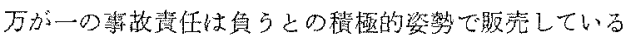

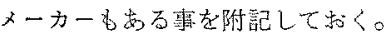

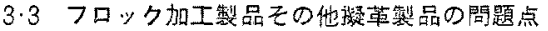

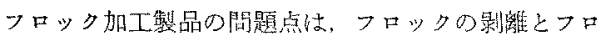

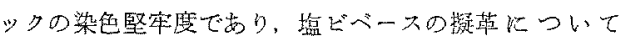
は，仃塑剂の溶脱又は移動がある。溶脱はドライクリー

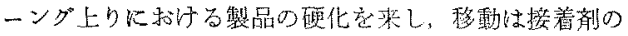

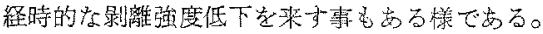

しかしフロック加工熋品については，JIS の規格およ び，接着剤の目覚しい進路により，间題点は少い管で㔖 り，七一タ一等の様な，生地安定性の極めて慗い承の沉 さ光，優秀な強度を持ったフロック加工がなされれている

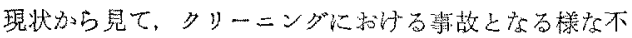

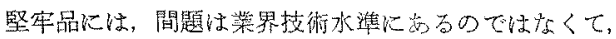

「商策上の無理」をした整品が可成り多いのでは告るま いか。フロックの染色堅寉磨の題题然り, 又塩ビベース のフロック加工擬㯰を，スーツやオーパー。ジャンパー

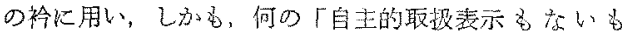
の」等，流通上の欠陷を鼠露したもの然りである。唯，

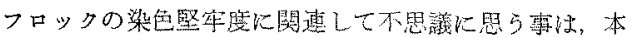
题と恃些か離れるがカーペットパイルのそれである。特 にレーヨンパイル又はアクリルレーヨン湿のレーヨンパ

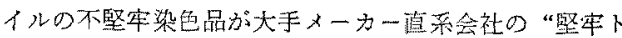

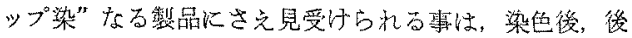

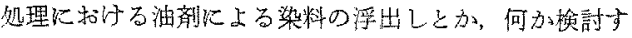


べき閪題点があるのではなかららか。

\section{$3 \cdot 4$ 樹脂择染品の問題点}

これ岕接着に関係するので，㛟討して見たい。

第一は、アゾ杀颜料のドライクリーニング溶剂溶出で

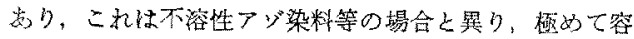
易にしかも，殆んど全部が溶出してしまう。パークレン

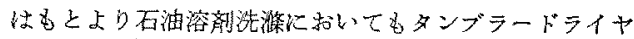
一処理に括いて同様の結果になる事性, 石油溶剂のア二 リン点が $40 \sim 60^{\circ} \mathrm{C}$ で岕る事から推察出来上ら。弗赘 系溶剂の処理のみに性涌えるが，消費者がそのサービス を受けられる便宜は今の処，未だ極めて少い。

第二は顔料樹拍撩染の中にドライクリーニングの「す み」に極めて弱いものがあることである。この間題は既 に 5〜6 年前に間题となり, 関連業者は知悉している筈

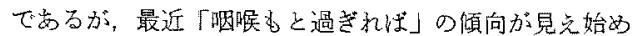
ている。これもドライクリーニングる必要とすると思わ れるウール物使用されている问きがあるので，少くも

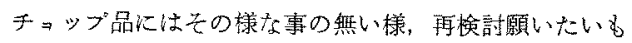
のでる。

\section{5 金属蒸着ラメ，バール加工等特秼品の}

接着加工の問題点

最淩に触れるこれらについては，本筫的には堅牢度性 末だ充分とはいえず，メーカ一側も用途に宊じて種々な むの定出している棓であるが，用途が少しず机ると事故

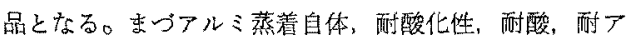
ルカル性上る，充分ではないので表面被膜により，堅年 性を茾うじて保つ状態で方るから，在料品としては当然 2プライが用いらるべきであるが，これらでさ古りり ーニング姃理剂，防虫剂，その他の影留で保存中心脱落 するるのが山る。況して使い唅て用として梨造されてい る1プライ製品が流用されれば忽ち間題の品之なる゙です ろう。次に，後者としては，パール加工など類似の名称 のもとに，模造真珠や，スパングルの表面加工に用いら れているものが程々专り，粗製品はドライクリーニング

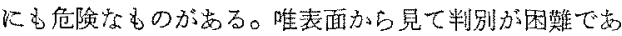

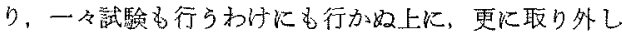
も出来ない様，デザイン的に維付けた製品が多いので， これも処置に困る製品の一つといえる。

\section{4.お おりに}

接着加工は今後益々姑らゆる分野に進出し貢献する技 術であると考える。

これ学受入れる側名，単にこれを無䡒任に利用するた けでなく，その特性を知って適材適所に利用する様努力 する事か゚必要であるが，それには先つ，供給側に和かれ

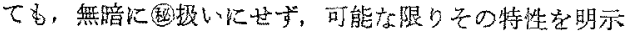
して生産と消貲との「断絶」を埋める事に協力して下さ る様希望する次第である。

\section{IBM 社が再度の挑戦}

IBM 社の発表によると, 現在、IBM 社は 2 種類の 新機種を開発しているということである。すなるち， System $/ 360$ model 195 と System/3 で嵓る[記 事 H300818 参熙り。 model 195 はこれ京で IBM が 生産した電子計算機のなかでもっと强力な計算機で 名る。逆にSystem/3は6っとも小さい計算機であ る。これによって，IBM は㖕算機有場のシェアをさ

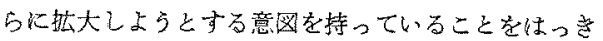
り示した。

これまでIBM 社が発壳してきた計算機のなかで最 大のスケールを持っているのは System/360の model 85 であった。 model 85 が主として事務用で山ったの に対し, 今回の model 195 は科学計算とタイムシェ ア用でるるとみられている。計算速度は model 195 の方が 85 より的 2 借速く， 八-ドウェアの基本サイ クル時間は $54 \mathrm{~ns}$ であり，主記恋装監の容量は約 400
カパイトである。しかも360シリーズとしての互換性 は完全に有しており，その他の機锺の入出力装置はす ベて model 195 に使用できる。

これまでIBM 社は大形計算機の市場に 2 度挑戦し てきた。第1回は 360-90であったが，これは全部で 20台しか壳れなかっだすな放ら失敗であった。2度 目の挑戦はいかわる'Stretch'と㭔ばれる機種であっ たが、こ杣計画倒れになってしまい工場で生産する といら段階に至らなかった。これ完全な失敗であ る。そこで，今回の mode1 195 は3 度目の挑戦约な るわけである。

大形電子計算機の市场梳これで Control Data Ltd．が独占してきたが，これと IBM 社がいかに戦 らか，世間の注目を集めている。

もし 195 が失敗与ると、IBM 社は大形市場から完 全に敗退することになるだろう。

D 193 Nature 223 [5209] 880 (Aug 30, 1969)

[海外技術ハイライト] Vol. 3，No. 9上り䎐载 